\title{
HUBUNGAN KONSUMSI KOPI DENGAN RISIKO DIABETES TIPE 2
}

\author{
Mutiara Fauza ${ }^{1}$ \\ ${ }^{1}$ Fakultas Kedokteran, Universitas Lampung
}

\begin{abstract}
The Relationship of Coffee Consumption with The Risk of Type 2 Diabetes. Type 2 diabetes or what is also known as diabetes mellitus is a chronic disease with high morbidity and mortality. The number of people with diabetes is increasing rapidly around the world. The International Diabetes Federation reports that in 2015, there were 415 million adults who had diabetes. By 2040, this number is expected to increase to 642 million. The risk of blindness, kidney disease, and amputation in people with type 2 diabetes mellitus is 20 to 40 times higher than in people without diabetes. Those with type 2 diabetes mellitus had a two to five times higher risk of having a myocardial infarction, and two to three times higher for having a stroke. Given its significant burden, identification of modifiable lifestyle factors is essential for diabetes prevention. Research by Akash et al (2013) has looked at the relationship between coffee consumption and diabetes mellitus. Research in several countries such as America, Europe, and Asia shows that coffee consumption reduces the risk of diabetes mellitus. Coffee contains hundreds of active compounds, as well as several substances that are thought to increase glucose absorption and glucose metabolism. Coffee is one of the most widely consumed beverages worldwide, thus investigating the relationship of coffee to various diseases has important health implications for society.
\end{abstract}

Keywords : coffee, diabetes mellitus, diabetes type 2

\begin{abstract}
Abstrak: Hubungan Kebiasaan Konsumsi Kopi Dengan Risiko Diabetes Tipe 2. Diabetes tipe 2 atau yang disebut juga sebagai diabetes melitus adalah penyakit kronis dengan angka morbiditas dan mortalitas yang tinggi. Jumlah penderita diabetes kian meningkat pesat di seluruh dunia. Federasi Diabetes Internasional melaporkan bahwa pada 2015, terdapat 415 juta orang dewasa yang menderita diabetes. Pada 2040, jumlah ini diperkirakan akan meningkat menjadi 642 juta jiwa. Risiko terjadinya kebutaan, penyakit ginjal, dan amputasi pada penderita diabetes melitus tipe 2 adalah 20 hingga 40 kali lebih tinggi dibandingkan orang tanpa diabetes. Mereka yang menderita diabetes melitus tipe 2 memiliki risiko dua hingga lima kali lebih tinggi untuk mengalami infark miokard, dan dua hingga tiga kali lebih tinggi untuk mengalami stroke. Mengingat bebannya yang signifikan, identifikasi faktor gaya hidup yang dapat dimodifikasi sangat penting untuk pencegahan diabetes. Penelitian oleh Akash et al (2013) telah melihat hubungan antara konsumsi kopi dengan diabetes melitus. Penelitian di beberapa negara seperti Amerika, Eropa, dan Asia memperlihatkan bahwa konsumsi kopi menurunkan risiko diabetes melitus. Kopi mengandung ratusan senyawa aktif, serta beberapa zat yang diduga dapat meningkatkan penyerapan glukosa dan metabolisme glukosa. Kopi adalah salah satu minuman yang banyak dikonsumsi seluruh dunia, dengan demikian menyelidiki hubungan kopi dengan berbagai penyakit memiliki implikasi kesehatan yang penting bagi masyarakat.
\end{abstract}

Kata Kunci : kopi, diabetes melitus, diabetes

\section{PENDAHULUAN}

Diabetes tipe 2 atau yang disebut juga sebagai diabetes melitus adalah penyakit kronis dengan angka morbiditas dan mortalitas yang tinggi. Jumlah penderita diabetes kian meningkat pesat di seluruh dunia. Federasi Diabetes Internasional 
melaporkan bahwa pada 2015, terdapat 415 juta orang dewasa yang menderita diabetes. Pada 2040, jumlah ini diperkirakan akan meningkat menjadi 642 juta jiwa (Ogurtsova et al., 2017).

Pada 2015, beban ekonomi global terkait dengan diabetes mencapai US \$ 1,31 triliun, dan ini menjadi beban ekonomi global yang cukup besar. Oleh karena itu, strategi dengan biaya rendah serta akses yang mudah untuk mencegah diabetes sangatlah diperlukan (Bommer et al., 2017).

Risiko terjadinya kebutaan, penyakit ginjal, dan amputasi pada penderita diabetes tipe 2 adalah 20 hingga 40 kali lebih tinggi dibandingkan orang tanpa diabetes. Mereka yang menderita diabetes melitus tipe 2 memiliki risiko dua hingga lima kali lebih tinggi untuk mengalami infark miokard, dan dua hingga tiga kali lebih tinggi untuk mengalami stroke. Mengingat bebannya yang signifikan, identifikasi faktor gaya hidup yang dapat dimodifikasi sangat penting untuk pencegahan diabetes (Trikkalinou, Papazafiropoulou, \& Melidonis, 2017).

Penelitian oleh Akash et al (2013) telah melihat hubungan antara konsumsi kopi dengan diabetes melitus. Penelitian di beberapa negara seperti Amerika, Eropa, dan Asia memperlihatkan bahwa konsumsi kopi menurunkan risiko diabetes melitus (Akash et al., 2013).

Kopi mengandung ratusan senyawa aktif, serta beberapa zat yang diduga dapat meningkatkan penyerapan glukosa dan metabolisme glukosa. Biological Plausibility pada kopi yaitu sebagai efek antiinflamasi yang dapat mendukung metabolisme glukosa (Kempf et al., 2010).

$$
\text { Penelitian }
$$

meta-analisis

menunjukkan bahwa konsumsi kopi terkait dengan risiko diabetes tipe 2 yang lebih rendah (Ding et al., 2014). Serupa dengan penelitian tersebut, sebuah penelitian yang dilakukan di cina menyatakan bahwa asupan kopi kahweol, asam klorogenat dan mikronutrien (Akash et al., 2013).

$$
\text { Kafein adalah salah satu }
$$
komponen utama yang telah diketahui berpengaruh secara positif dengan fungsi sel beta pankreas pada populasi dengan risiko tinggi mengalami diabetes mellitus (Gao et al., 2018). Dua penelitian yang dilakukan di Korea juga menunjukkan hubungan yang terbalik antara konsumsi kopi dan risiko DM dimana dinyatakan bahwa semakin sering seseorang mengkonsumsi kopi, semakin rendah pula risiko dirinya menderita diabetes (Lim et al., 2019).

Keyakinan masyarakat akan manfaat atau risiko kesehatan dari kopi belum sepenuhnya diyakini. Terdapat kalangan orang yang menghindari konsumsi kopi untuk alasan medis seperti kecemasan dan insomnia (Sousa et al., 2016) atau karena keyakinan bahwa kopi pada umumnya berdampak buruk kesehatan (ISIC, 2016). Minum kopi tidak dianggap sebagai perilaku yang berorientasi pada kesehatan, meskipun bukti ilmiah menunjukkan bahwa kopi dapat menjadi bagian dari makanan sehat (Grosso, Godos, Galvano, \& Giovannucci, 2017). Masalah kesehatan utama muncul berkaitan dengan kandungan kafein dalam kopi (Wikoff et al., 2017). Masyarakat melihat kopi kebanyakan sebagai stimulan dan tidak mengetahui tentang komponen bermanfaat yang dikandung oleh kopi (ISIC, 2016). Dengan demikian menyelidiki hubungan kopi dengan berbagai penyakit memiliki implikasi kesehatan yang penting bagi masyarakat (Akash et al., 2013).

\section{METODE}

Penelitian ini dilakukan dengan cara mengumpulkan artikel ilmiah penelitian sebelumnya untuk mendapatkan informasi dan membuat ringkasan berupa review artikel ilmiah.

\section{PEMBAHASAN}

Kopi mengandung banyak sekali komponen. Komponen kopi diantaranya adalah kafein, cafestol, dapat meningkatkan sekresi insulin. Terbukti konsentrasi insulin cenderung lebih tinggi pada 30 menit pertama setelah konsumsi kopi berkafein 
dibandingkan dengan kopi atau air tanpa kafein (Gao et al., 2018). Kafein dapat berdampak pada konsentrasi glukosa darah melalui beberapa mekanisme. Kafein dapat menghambat transportasi glukosa dari darah ke otot melalui perannya sebagai antagonis reseptor adenosin, selanjutnya kafein akan menghambat penyerapan glukosa kedalam sel otot. Dalam studi eksperimental, intake moderat kafein telah terbukti mengganggu kontrol glikemik pada orang sehat. Kafein mengganggu metabolisme glukosa pada pasien dengan diabetes (Whitehead \& White, 2013). Toleransi terhadap efek kafein ini dapat berkembang setelah asupan jangka panjang. Selain itu, phytochemical seperti asam klorogenat dan trigonelin, dapat meningkatkan metabolism glukosa melalui efek menguntungkan pada stress oksidatif, gluconeogenesis, hormone usus atau mikroflora usus (Wedick et al., 2011).

Asam klorogenat adalah bahan utama lain yang terdapat didalam kopi. Asam klorogenat terdiri dari kelas utama senyawa fenolik, terutama berasal dari esterifikasi asam transcinnamic (caffeic, ferulic, dan $P$ coumaric) (Farah, 2012). Terdapat studi yang membuktikan bahwa asam klorogenat dapat merangsang produksi glukagon-like peptide 1 (GLP-1) yang merupakan salah satu hormon gastrointestinal dan diketahui memiliki efek pada fungsi sel beta pankreas yang memperkuat sekresi insulin yang bergantung pada glukosa. Asam klorogenat sebagai antioksidan kuat dapat membantu mengatur kadar gula darah dan mengurangi risiko diabetes dengan menghambat penyerapan glukosa usus dan meningkatkan sensitivitas insulin (Lee et al., 2016). Berdasarkan penelitian asam klorogenat dilaporkan sebagai penghambat translokasi glukosa- 6 fosfat yang dapat menunda absorbsi glukosa dalam saluran gastrointestinal (Kobayashi et al., 2017). Apabila absorbsi glukosa dapat ditunda maka kadar glukosa dalam darah akan naik secara perlahan, sehingga menghindari terjadinya hiperglikemi yang merupakan salah satu penyebab resistensi insulin. Selain itu, asam klorogenat berfungsi mengurangi oksidasi small dense LDL (low density lipoprotein). Oksidasi LDL ini dapat mempengaruhi resistensi insulin yang dapat menyebabkan diabetes mellitus tipe 2. (Gerber et al., 2012).

Kandungan kopi lainnya yang juga berperan dalam menurunkan risiko diabetes mellitus adalah cafestol dan kahweol. Cafestol dan kahweol dilaporkan sebagai senyawa yang berperan untuk membantu memberikan sinyal PPAR $\gamma$ (Peroxisome Proliferator Activated Receptors gamma). Fungsi PPAR $\gamma$ sebagai reseptor ligan yang terletak dalam inti dan merupakan faktor transkripsi gen yang mempengaruhi fungsi insulin atau sebagai titik tumpu regulasi insulin (Akash et al., 2013).

Di sisi lain, magnesium yang merupakan mikronutrien juga terbukti meningkat fungsi sel beta pankreas. Studi sebelumnya menemukan bahwa peningkatan eritrosit magnesium secara signifikan dan positif berkorelasi dengan peningkatan sekresi insulin (Gao et al., 2018).

Penelitian di Amerika menyatakan, temuan dari tinjauan sistematis dan meta-analisis terhadap 1.109.272 peserta studi dan 45.335 kasus diabetes melitus tipe 2, menunjukkan terdapat hubungan terbalik yang kuat antara konsumsi kopi dan risiko diabetes. Individu yang mengkonsumsi kopi 6 cangkir / hari dikaitkan dengan risiko 33\% lebih rendah mengalami diabetes mellitus tipe 2. Kopi berkafein dan tidak berkafein berkaitan dengan rendahnya risiko individu yang mengkonsumsi kopi untuk mengalami diabetes mellitus tipe 2. Pada asosiasi terbalik antara kopi konsumsi dan risiko diabetes telah didemonstrasikan pada model hewan dan studi in vitro yang melibatkan beberapa komponen kopi dalam mengurangi resistensi insulin dan meningkatkan metabolisme glukosa. Asam klorogenat, senyawa fenolik, adalah komponen kopi utama yang 
telah terbukti mengurangi konsentrasi glukosa darah pada hewan percobaan (Ding et al, 2014).

\section{KESIMPULAN}

Kandungan senyawa dalam kopi yakni kafein, asam klorogenat, cafestol, kahweol, juga magnesium dapat berperan dalam pengaturan kadar gula darah, melalui mekanisme peningkatan sensitivitas insulin juga penghambatan absorpsi glukosa pada gastrointestinal. Dengan demikian, konsumsi kopi dapat menurunkan risiko terjadinya diabetes mellitus.

\section{DAFTAR PUSTAKA}

Akash MS, Rehman K, \& Chen S. (2013). Effects of coffee on type 2 diabetes mellitus. Nutrition, 30(7-8): 755-63.

Bommer C, Heesemann E, Sagalova V, Manne-Goehler J, Atun R, Bärnighausen $T$, \& Vollmer S. (2017). The global economic burden of diabetes in adults aged 2079 years: a cost-of-illness study. Lancet Diabetes Endocrinol, 5(6): 423-430

Ding M, Bhupathiraju SN, Chen M, van Dam RM, \& Hu FB. (2014). Caffeinated and decaffeinated coffee consumption and risk of type 2 diabetes: a systematic review and a dose-response metaanalysis. Diabetes Care, 37(2): 569-86.

Farah, A. (2012). Coffee Constituents, in: Chu Y. -F. (Ed). Coffee. Wiley-Blackwell. 21-58.

Gao F, Zhang Y, Ge S, Lu H, Chen R, Fang $P$, Shen $Y$, Wang $C$, \& Jia W. (2018). Coffee consumption is positively related to insulin secretion in the Shanghai High-Risk Diabetic Screen (SHiDS) Study. Nutrition \& Metabolism, (15): 84

Gerber PA, Spinas GA, \& Berneis K. (2012). Small dense lowdensity lipoprotein particles: priority as a treatment target in Type 2 diabetes. Diabetes Manage, 2(1): 6574.

Institute for Scientific Information on Coffee (ISIC). Roundtable Report. The Good Things in Life: Coffee as Part of a Healthy Diet and Lifestyle; ISIC: Worcestershire, UK, 2016.

https://www.coffeeandhealt h.org/wpcontent/uploads/2016/03/R oundtable-report_Coffee-aspart-of-a-healthy-diet.pdf (diakses pada 29 september 2020).

Kempf $\mathrm{K}$, Herder C, Erlund L, Kolb $\mathrm{H}$, Martin $S$, Carstensen $M$, Koenig W, Sundvall J, Bidel S, Kuha S, \& Jaakko T. (2010). Effects of coffee consumption on subclinical inflammation and other risk factor for type 2 diabetes. clinical trial. Am J Clin Nutr, (91): 950-957.

Kobayashi M, Kurata T, Hamana Y, Hiramitsu M, Inoue T, Murai A, \& Horio F. (2017). Coffee Ingestion Supresses Hyperglycemia in Streptozotocin-Induced Diabetic Mice. J Nutr Sci, (63): 200-207.

Lee JH, Oh MK, Lim JT, Kim HG, \& Lee WJ. (2016). Effect of Coffee Consumption on the Progression of Type 2 Diabetes Mellitus among Prediabetic Individuals. Korean J Fam Med, (37): 713.

Lim Y, Park Y, Choi SK, Ahn S, Ohn JH. (2019). The Effect of Coffee Consumption on the Prevalence of Diabetes Mellitus: The 2012-2016 Korea National Health and Nutrition Examination Survey. Nutrients, 11(10): 2377

Ogurtsova K, da Rocha Fernandes JD, Huang $Y$, Linnenkamp $U$, 
Guariguata L, Cho NH, Cavan D, Shaw $\mathrm{JE}, \quad \& \quad$ Makaroff LE. (2017).IDF Diabetes Atlas: Global estimates for the prevalence of diabetes for 2015 and 2040. Diabetes Res Clin Pract, (128): 4050.

Sousa AG, Machado LMM, da Silva EF, \& da Costa THM. (2016). Personal characteristics of coffee consumers and nonconsumers, reasons and preferences for foods eaten with coffee among adults from the Federal District, Brazil. Food Sci. Technol, (36): 432-438.

Trikkalinou A, Papazafiropoulou AK, \& Melidonis A. (2017). Type 2 diabetes and quality of life. World J Diabetes, 8(4): 120-129.

Wedick NM, Brennan AM, Sun Q, Hu FB, Mantzoros CS, \& Van Dam RM. (2011). Effects of caffeinated and

Hum Nutr Diet, (26): 111-125. decaffeinated coffee on biological risk factors for type 2 diabetes: a randomized controlled trial. Nutr J, (10): 93.

Wikoff D, Welsh BT, Henderson R, Brorby GP, Britt J, Myers E, Goldberger J, Lieberman HR, O'Brien C, Peck J, et al. (2017). Systematic review of the potential adverse effects of caffeine consumption in healthy adults, pregnant women, adolescents, and children. Food Chem Toxicol, (109): 585-648.

Whitehead N \& White H. (2013). Systematic review of randomized controlled trials of the effects of caffeine or caffeinated drinks on blood glucose concentrations and insulin sensitivity in people with diabetes mellitus. $J$ 